\title{
Temperature and substrate on Plukenetia volubilis L. seed germination
}

\author{
Givanildo Z. da Silva ${ }^{1}$, Vanessa A. C. Vieira², João E. B. Boneti ${ }^{3}$, Lilian F. Melo ${ }^{1}$ \& Cibele C. Martins ${ }^{1}$ \\ ${ }^{1}$ Universidade Estadual Paulista Júlio de Mesquita Filho/Faculdade de Ciências Agrárias e Veterinárias/Departamento de Produção Vegetal. Jaboticabal, SP. \\ E-mail: givanildozildo@hotmail.com; lilianfariamelo@gmail.com; cibele@fcav.unesp.br (Corresponding author) \\ ${ }^{2}$ Universidade Estatual do Mato Grosso do Sul/Departamento de Produção Vegetal. Aquidauana, MS. E-mail: vanessacassolvieira@hotmai.com \\ ${ }^{3}$ Instituto Agronômico de Campinas/Centro Avançado de Pesquisa Tecnológica do Agronegócio de Cana. Ribeirão Preto, SP. E-mail: joaoboneti86@gmail.com
}

\section{Key words:}

sacha inchi

oil crop

Euphorbiaceae

omega-3

Amazon plant

\begin{abstract}
A B S T R A C T
The objective of this work was to evaluate the effect of temperature and substrate on the germination of $P$. volubilis seeds. Seeds harvested from 25 matrix plants were submitted, in two studies, to conditions of (i) sowing in rolled paper towel at the temperatures of 10,15 , $20,25,30,35,40$, and $45^{\circ} \mathrm{C}$, for the evaluation of germination, first count of germination, germination speed index and mean time for germination, and (ii) sowing in the substrates paper towel, sand, Bioplant $t^{\oplus}$, Bioplant ${ }^{\oplus}$ and micron, superfine, fine, medium and coarse vermiculite. The same evaluations mentioned in the first study were conducted at the temperature of $30^{\circ} \mathrm{C}$, as well as plant growth. The treatment replicates were distributed in a completely randomized block design and the effects of temperature were compared by polynomial regression analysis. The substrates were compared by the Scott-Knott test at 0.05 probability level. The data show that the ideal range of temperature for the germination of $P$. volubilis is between 25 and $30^{\circ} \mathrm{C}$. The temperature of $20^{\circ} \mathrm{C}$ is the minimum for germination and those above $35^{\circ} \mathrm{C}$ are lethal to these seeds. The most favorable substrate for $P$. volubilis seed germination is micron or fine vermiculite.
\end{abstract}

\section{Palavras-chave:}

sacha inchi

oleaginosa

Euphorbiaceae

ômega-3

planta da Amazônia

\section{Temperatura e substrato na germinação de sementes de Plukenetia volubilis L.}

\begin{abstract}
R E S U M O
Objetivou-se, neste trabalho, avaliar o efeito de temperaturas e substratos na germinação de sementes de $P$. volubilis. Sementes colhidas em 25 plantas matrizes foram avaliadas em dois estudos: (i) semeadura em rolo de papel nas temperaturas 10, 15, 20, 25, 30, 35, 40 e $45^{\circ} \mathrm{C}$, avaliando-se a germinação, primeira contagem, índice de velocidade de germinação e tempo médio de germinação; e (ii) semeadura nos substratos rolo de papel, entre areia, entre Basaplant ${ }^{\oplus}$, entre Bioplant ${ }^{\oplus}$ e entre vermiculita mícron, superfina, fina, média e grossa; conduzindo-se a $30^{\circ} \mathrm{C}$ os mesmos testes descritos no primeiro estudo e também o crescimento de plântulas. Os dados foram analisados em delineamento inteiramente casualizado com análise de regressão polinomial para a avaliação das temperaturas. Para a comparação entre os substratos utilizou-se o teste de Scott Knott, a 0,05 de probabilidade. Conclui-se que a germinação de sementes de $P$. volubilis deve ser conduzida nas temperaturas de 25 a $30^{\circ} \mathrm{C}$. A temperatura de $20^{\circ} \mathrm{C}$ é a mínima para a germinação e as acima de $35^{\circ} \mathrm{C}$ são letais para essas sementes. O substrato mais favorável à germinação de sementes de $P$. volubilis é a vermiculita mícron ou fina.
\end{abstract}




\section{INTRODUCTION}

Plukenetia volubilis $\mathrm{L}$. is a semi-perennial climbing plant from the Amazon, cultivated in Peru (Hamaker et al., 1992) and Colombia (Gutiérrez et al., 2011). The oil extracted from its seeds has been industrialized by the pharmaceutical and cosmetic sectors, which has increased the demand for seedlings for planting (Follegatti-Romero et al., 2009; Gutiérrez et al., 2011; Ruiz et al., 2013). For the production of seedlings of a certain species, it is important to identify temperatures and substrates that favor their germination and growth (Martins et al., 2012). Temperature acts on the speed of water absorption and biochemical reactions that determine the entire process of germination, and the substrate is also important, because its chemical composition, texture and structure influence the availability of water, oxygen, light and nutrients (Lima et al., 2010; Weitbrecht et al., 2011; Silva et al., 2014).

Therefore, as favorable substrates for seed germination, studies have reported sand, for Solanum sessiliflorum Dunal (Lopes \& Pereira, 2005), and vermiculite, for Acosmium nitens (Vog.) Yakovlev and Eugenia uniflora L. (Varela et al., 2005; Sena et al., 2010), as examples of species that occur in the Amazon. For subtropical and tropical forest species, the optimal temperature for germination is usually situated between 20 and $30^{\circ} \mathrm{C}$, since these temperatures occur in their regions of origin in the period favorable to natural germination (Borges \& Toorop, 2015). The temperature of $25{ }^{\circ} \mathrm{C}$ is ideal for the germination of seeds of $S$. sessiliflorum, Copaifera langsdorffi Desf. and Anadenanthera colubrina (Vellozo) Brenan (Lopes \& Pereira, 2005; Brasil, 2013), while $30{ }^{\circ} \mathrm{C}$ is ideal for A. nitens, Theobroma grandiflorum (Wild ex Spreng Schum) and Genipa americana L. (Varela et al., 2005; Ferraz et al., 2012; Brasil, 2013), because they allow maximum germination in the shortest period of time.

In this context and due to the lack of information on the optimal temperature and the adequate substrate for the germination of this species, this study aimed to evaluate the effect of temperatures and substrates on the germination of $P$. volubilis seeds.

\section{Material AND Methods}

P. volubilis seeds were obtained from ripe fruits, with dark brown color, harvested in the crown of 25 matrix trees in Manaus, AM ( $3^{\circ} 8^{\prime} \mathrm{S}$; $59^{\circ} 52^{\prime} \mathrm{W}$ ). After drying the fruits in the shade, the seeds were extracted, placed in Kraft paper bag and taken to the laboratory. The seeds had water content of $8 \%$, determined at $105 \pm 3{ }^{\circ} \mathrm{C}$ for $24 \mathrm{~h}$ (Brasil, 2009). The germination potential of the seeds was evaluated in two studies:

The first study evaluated germination temperatures of 10 , $20,25,30,35,40$ and $45^{\circ} \mathrm{C}$ in regime of $8 \mathrm{~h}$ of light and $16 \mathrm{~h}$ of darkness. For this, four replicates of 20 seeds were sown in each treatment, in rolls of paper towel previously moistened with distilled water, at the proportion of 2.5 times the dry weight of the substrate. Germinated seedlings were considered as those with hypocotyl-radicle axis longer than $6 \mathrm{~cm}$ and epicotyl present between the cotyledons at 60 days after sowing. The results were expressed in percentage of germination (Brasil,
2009). Simultaneously to the germination test, the speed of the process was evaluated through the following variables:

First count of germination - performed 9 days after sowing, through the count of the normal seedlings present in the test. The counting date was established based on the criterion of $50 \%$ of seed germination in most treatments (Brasil, 2009; Ferraz et al., 2012).

Germination speed index - determined through counts every two days and applying the equation established by Maguire (1962).

Mean time for germination - calculated using the formula proposed by Labouriau \& Valadares (1976), with results expressed in days.

The second study evaluated the following substrates: roll of paper towel, between sand, between Basaplant (Pine bark, vermiculite, peat, charcoal, nitrogen, phosphorus, potassium and micronutrients), between Bioplant Prata (Pine bark, aged manure, sawdust, coconut fiber, vermiculite, rice hull, ash, agricultural gypsum, calcium carbonate, magnesium, magnesium thermophosphate, nitrogen, phosphorus, potassium and micronutrients) (Lopes et al., 2013; Bioplant, 2015) and between micron (particles smaller than $0.46 \mathrm{~mm}$ ), superfine (particles smaller than $0.65 \mathrm{~mm}$ ), fine (particles smaller than $1.29 \mathrm{~mm}$ ), medium (particles smaller than $2.60 \mathrm{~mm}$ ) and coarse (particles smaller than $5.20 \mathrm{~mm}$ ) vermiculites (Ugarte et al., 2005).

The tests were installed with seven replicates of 20 seeds and conducted at the most favorable temperature, identified in the previous step. The substrate paper was moistened with 2.5 times its dry weight in water. The sand, commercial substrates and vermiculite were moistened with $60 \%$ of their water retention capacity, according to the recommendations for sand of the Rules for Seed Analysis (Brasil, 2009). Germination in sand, Basaplant, Bioplant and vermiculite was conducted in transparent plastic boxes $(18.0 \times 13.5 \times 6.5 \mathrm{~cm})$ containing 2.0 $\mathrm{cm}$ of substrate, with sowing performed at the depth of $1.0 \mathrm{~cm}$.

The effect of the substrates on the germination performance of the seeds was evaluated by the previously described tests of germination, first count of germination and germination speed index. At the end of the test, the percentages of hard and dead seeds were also calculated.

The normal seedlings produced were measured using a ruler graduated in centimeter for the determination of shoot length (from the base to the insertion of the first leaf) and root length (from the apex of the main root to the base). The weight of shoot and root dry matter of the seedlings was determined after drying the normal seedlings in Kraft paper bags in a forced-air oven at $65^{\circ} \mathrm{C}$ for $48 \mathrm{~h}$ (Nakagawa, 1999).

The statistical design was completely randomized. For the evaluation of temperatures, the means were fitted to polynomial regression models, while the means of the substrates were compared by the Scott-Knott at 0.05 probability level. Before the analyses, the percent data were transformed to arc sine $((x+1) / 100)^{1 / 2}$ (Banzatto \& Kronka, 2006). The means presented in the tables are from the original data.

\section{Results AND Discussion}

There was significant effect of temperature on all variables related to the germination of $P$. volubilis seeds 


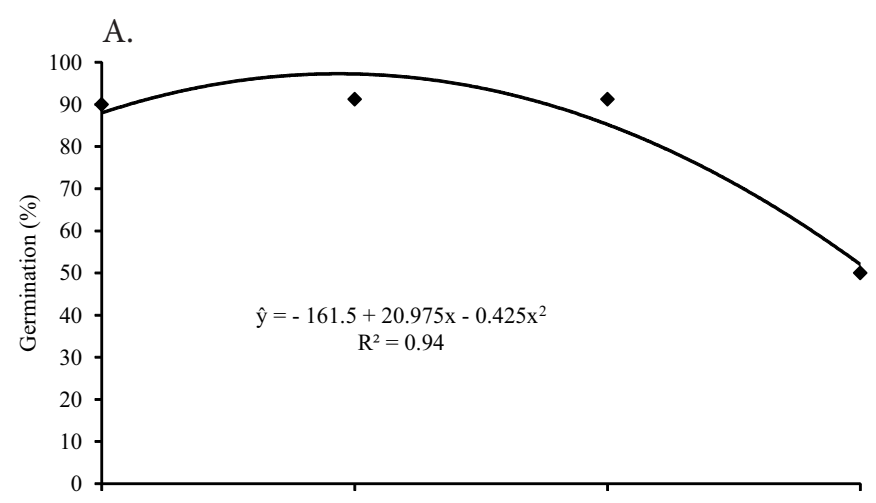

B.
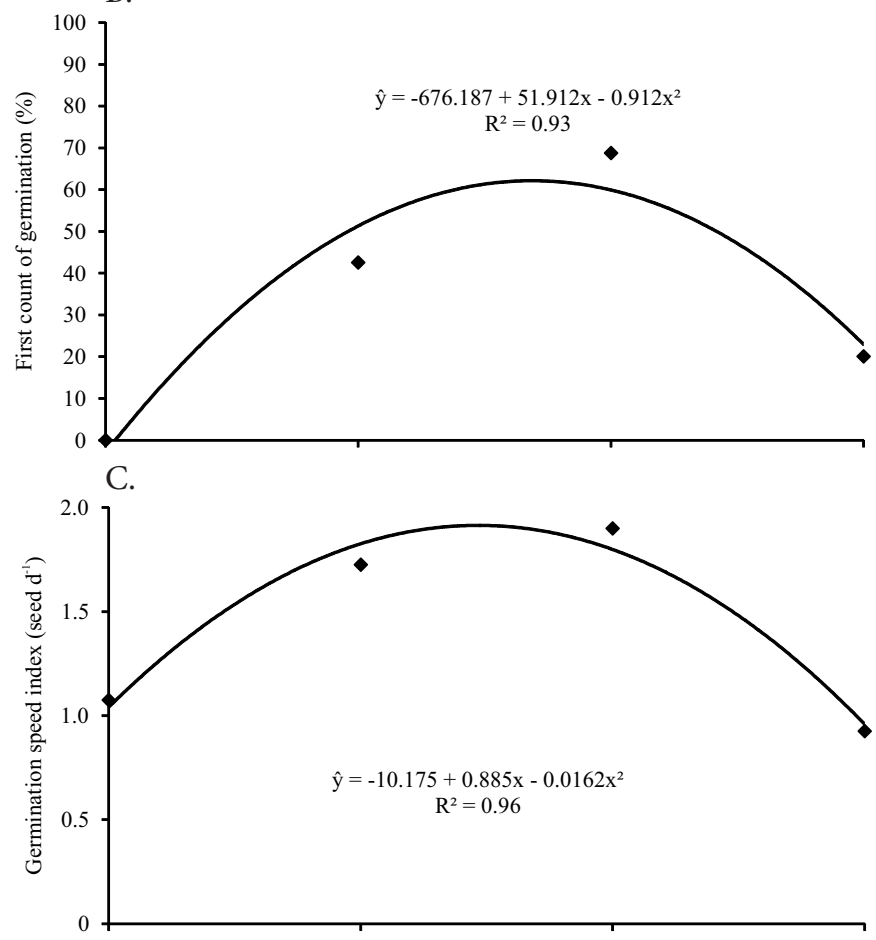

D.

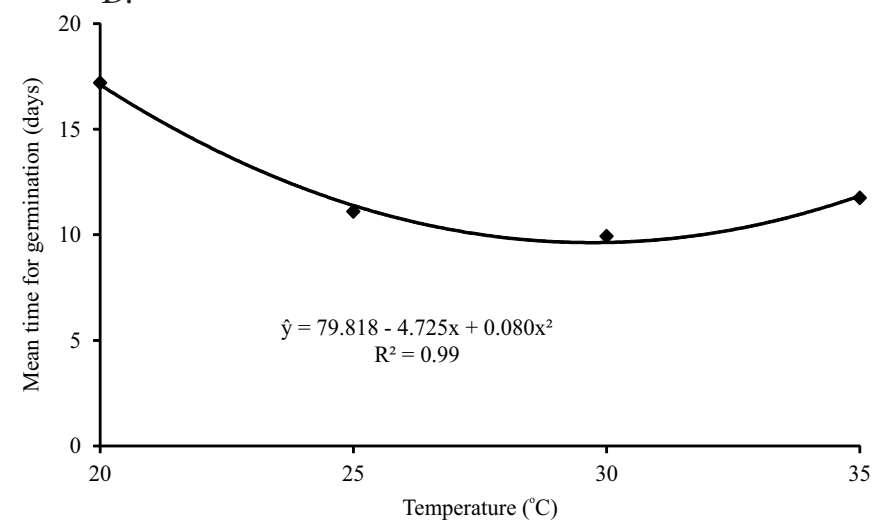

Figure 1. Germination (A), first count of germination (B), germination speed index $(C)$ and mean time for germination (D) of Plukenetia volubilis L. seeds germinated at different temperatures

(Figure 1). Germination occurred between 20 and $35^{\circ} \mathrm{C}$, with maximum of $97 \%$ at $25^{\circ} \mathrm{C}$ (Figure 1A). The temperature of $25{ }^{\circ} \mathrm{C}$ has also been recommended for the conduction of germination tests of other Euphorbiaceae plants, such as T. grandiflorum, Croton floribundus Spreng and Croton urucurana Baill, J. curcas and Joannesia princeps Vellozo (Ferraz et al., 2012; Brasil, 2013).
At temperatures above $30^{\circ} \mathrm{C}$, there was a tendency of reduction in germination, intensified at $35^{\circ} \mathrm{C}$ (Figure $1 \mathrm{~A}$ ). The sharp decrease in the germination percentage of the seeds from $35^{\circ} \mathrm{C}$ on must have been caused by damages to their structure, because high temperatures inhibit embryo development, cause enzymatic alterations and reduce the amount of free amino acids of the synthesis of RNA, modifying the speed of metabolic reactions (Weitbrecht et al., 2011; Borges \& Toorop, 2015).

At temperatures lower than $20^{\circ} \mathrm{C}$, between 10 and $15^{\circ} \mathrm{C}$, it was possible to observe that the seeds absorbed water, because they increased in size; however, germination did not complete and there was no production of root, even after 60 days of test. Therefore, $15^{\circ} \mathrm{C}$ can be classified as the minimum temperature, the value below which germination does not occur (Carvalho \& Nakagawa, 2012).

The absence of germination was also observed in seeds that germinated at temperatures above $35^{\circ} \mathrm{C}$ (between 40 and $45^{\circ} \mathrm{C}$ ); however, at the latter ones, $P$. volubilis seeds showed evident signs of deterioration and death, such as: darkened tegument, fungi proliferation and release of exudates in the substrate. Hence, for the seeds of this species, the temperature of $40{ }^{\circ} \mathrm{C}$ can be classified as maximum temperature, the value above which germination does not occur (Carvalho \& Nakagawa, 2012).

In the evaluation of germination speed through the tests of first count, speed index and mean time for germination, the best performances of the seeds (62\% of germination, speed index of 1.91 and time of 10 days for germination) were observed at 29, 27 and $30^{\circ} \mathrm{C}$, respectively (Figure 1B, C and $\mathrm{D})$. Therefore, the temperatures most favorable to germination speed and that allowed the formation of seedlings in shorter time were higher than those observed to obtain maximum germination percentage, as reported for the seeds of J. curcas (Pascuali et al., 2012). This phenomenon can be explained by the acceleration of the metabolic reactions of the seeds due to the high temperatures, associated with the denaturation of proteins and alteration of cell membranes, so that the number of seeds that are able to complete germination rapidly decreases (Kapoor et al., 2011).

Considering the data of final germination percentage and the speed of this process, it is inferred that temperatures between 25 and $30^{\circ} \mathrm{C}$ can be considered as optimal for the conduction of the test of seed germination and production of $P$. volubilis seedlings (Figure 1), because they allowed maximum germination in the shortest time.

As to the effect of the substrates on $P$. volubilis germination, micron and fine vermiculites allowed maximum seed germination, with values of 92 and $95 \%$, respectively. These percentages of germination were significantly higher than those of the seeds in the other substrates tested (Table 1).

It should be pointed out that the vermiculite with these two particle sizes led to favorable results to the seeds, which were similar with respect to the germination speed index and the percentages of hard and dead seeds; however, the fine vermiculite allowed a faster germination compared with micron vermiculite, according to the test of first count, with values of 64 and 54\%, respectively.

Germination speed can be influenced by the texture of the substrate and, depending on the species, the seeds may 
Table 1. Mean values of germination percentage (G), first count of germination (FCG), germination speed index (GSI), hard seeds $(\mathrm{H})$ and dead seeds (D) of Plukenetia volubilis L. from different substrates

\begin{tabular}{|c|c|c|c|c|c|}
\hline \multirow{2}{*}{ Substrates } & G & FCG & \multirow{2}{*}{ GSI } & H & D \\
\hline & \multicolumn{2}{|c|}{$(\%)$} & & \multicolumn{2}{|c|}{$(\%)$} \\
\hline Paper & $71 \mathrm{c}$ & $67 \mathrm{a}$ & $1.44 \mathrm{~b}$ & $0 \mathrm{a}$ & $29 \mathrm{~b}$ \\
\hline Sand & $87 \mathrm{~b}$ & $67 \mathrm{a}$ & $1.52 \mathrm{a}$ & $9 \mathrm{~b}$ & $4 a$ \\
\hline Bioplant ${ }^{\circledR}$ & $79 \mathrm{~b}$ & $44 \mathrm{~b}$ & $1.31 \mathrm{~b}$ & $13 b$ & $8 a$ \\
\hline Basaplant $^{\circledR}$ & $56 \mathrm{~d}$ & $2 \mathrm{e}$ & $0.69 \mathrm{~d}$ & $39 c$ & $5 \mathrm{a}$ \\
\hline Micron vermiculite & $92 \mathrm{a}$ & $54 \mathrm{~b}$ & $1.56 \mathrm{a}$ & $5 \mathrm{a}$ & $3 a$ \\
\hline Superfine vermiculite & $82 \mathrm{~b}$ & $13 d$ & $1.14 \mathrm{C}$ & $13 b$ & $5 a$ \\
\hline Fine vermiculite & $95 \mathrm{a}$ & $64 \mathrm{a}$ & $1.60 \mathrm{a}$ & $1 \mathrm{a}$ & $4 \mathrm{a}$ \\
\hline Medium vermiculite & $87 \mathrm{~b}$ & $59 a$ & $1.39 \mathrm{~b}$ & $2 \mathrm{a}$ & $11 \mathrm{a}$ \\
\hline Coarse vermiculite & $56 \mathrm{~d}$ & $27 \mathrm{c}$ & $1.00 \mathrm{c}$ & $32 \mathrm{c}$ & $12 \mathrm{a}$ \\
\hline F treatment & $24.8^{\star *}$ & $39.2^{\star *}$ & $21.5^{* *}$ & $25.0^{* *}$ & $4.9^{\star *}$ \\
\hline C.V. (\%) & 9.9 & 23.3 & 13.2 & 32.0 & 48.1 \\
\hline
\end{tabular}

${ }^{*}$ Significant by $\mathrm{F}$ test at 0.01 probability level. Means followed by the same letter in the column do not differ by the Scott-Knott test at 0.05 probability level

exhibit better germination performance in vermiculite with certain granulometry. This phenomenon was observed for seeds of Archontophoenix alexandrae $\mathrm{H}$. Wendl \& Drude in micron vermiculite (Martins et al., 2011), E. uniflora (Sena et al., 2010) and Adenanthera pavonina L. (Alves et al., 2015) in fine vermiculite.

Basaplant and coarse vermiculite were the least adequate substrates for the germination of $P$. volublis seeds, because they led to the lowest percentages of germination and highest percentages of hard seeds. A probable reason for this phenomenon would be a lower water retention capacity of these substrates in comparison to the others, as reported by Alves et al. (2015) for seeds of A. pavonina. Another factor that may have influenced water absorption by the seed is the area of contact between the seed coat and the substrate (Carvalho \& Nakagawa, 2012), considering that substrates with larger particle sizes have smaller surface of contact with the seeds.

The other substrates, paper, sand, Bioplant and superfine and medium vermiculite, led to intermediate values of germination, between 71 and $87 \%$, and the seeds that did not germinate in the roll of paper were dead (Table 1). Therefore, it can be claimed that the substrate paper caused the death of the seeds, as observed for the seeds of other species of the Amazon, such as S. sessiliflorum (Lopes \& Pereira, 2005) and A. nitens (Varela et al., 2005).

The substrate roll of paper is the most used for the standard test of germination according to the Rules for Seed Analysis (Brasil, 2009), due to the ease of standardization, practicality in the utilization and disposal and for occupying less space in the storage.

The utilization of Bioplant as substrate allowed maximum growth of $P$. volubilis seedlings, observed through the length and dry matter of shoots and roots, in comparison to the others, although it did not differ regarding shoot dry matter from seedlings produced in micron vermiculite (Table 2 ).

Bioplant ${ }^{\circ}$ has in its composition calcium carbonate, magnesium, magnesium thermophosphate, ashes, aged manure, coconut fiber, rice hull and sawdust; these components are not found in the other substrates (Lopes et al., 2013; Bioplant, 2015). Therefore, from seed germination and root
Table 2. Mean values of length and dry matter of shoots and roots of Plukenetia volubilis L. seedlings from different substrates

\begin{tabular}{|c|c|c|c|c|}
\hline \multirow{2}{*}{ Substrates } & \multicolumn{2}{|c|}{ Length (cm) } & \multicolumn{2}{|c|}{ Dry matter (g) } \\
\hline & Shoots & Roots & Shoots & Roots \\
\hline Paper & $4.4 \mathrm{e}$ & $12.3 \mathrm{~b}$ & $0.139 d$ & $0.082 \mathrm{c}$ \\
\hline Sand & $10.8 \mathrm{c}$ & $8.3 d$ & $0.297 \mathrm{~b}$ & $0.091 \mathrm{C}$ \\
\hline Bioplant ${ }^{\circledR}$ & $22.4 \mathrm{a}$ & $14.9 \mathrm{a}$ & $0.383 \mathrm{a}$ & $0.166 \mathrm{a}$ \\
\hline Basaplant ${ }^{\circledR}$ & $8.7 \mathrm{~d}$ & $8.3 d$ & $0.272 \mathrm{c}$ & $0.119 b$ \\
\hline Micron vermiculite & $16.8 b$ & $11.2 \mathrm{c}$ & $0.371 \mathrm{a}$ & $0.139 b$ \\
\hline Superfine vermiculite & $8.7 \mathrm{~d}$ & $9.0 \mathrm{~d}$ & $0.261 \mathrm{c}$ & $0.134 \mathrm{~b}$ \\
\hline Fine vermiculite & $16.5 b$ & $9.6 \mathrm{~d}$ & $0.327 \mathrm{~b}$ & $0.136 \mathrm{~b}$ \\
\hline Medium vermiculite & $10.9 \mathrm{c}$ & $13.3 \mathrm{~b}$ & $0.305 b$ & $0.146 b$ \\
\hline Coarse vermiculite & $11.4 \mathrm{C}$ & $10.6 \mathrm{c}$ & $0.323 b$ & $0.126 b$ \\
\hline F treatment & $84.9^{* *}$ & $14.5^{* \star}$ & $18.7^{\star *}$ & $9.2^{* \star}$ \\
\hline C.V $(\%)$ & 12.60 & 13.97 & 14.83 & 18.20 \\
\hline
\end{tabular}

** Significant by $F$ test at 0.01 probability level. Means followed by the same letter do not differ by the Scott-Knott test at 0.05 probability level

growth on, the absorption of the nutrients present in the substrate and their mobilization to the structures of the seedlings began, promoting their development, as observed for Peltophorum dubium (Spreng.) Taub. by Dutra et al. (2012).

Although Bioplant favored the growth of the seedlings, it was not one of the most favorable to seed germination; hence, a strategy that could be used for the production of $P$. volubilis seedlings would be the planting of seeds in micron or fine vermiculite and later transplanting the pre-germinated seeds to the substrate Bioplant ${ }^{\circ}$.

\section{Conclusions}

1. The germination of $P$. volubilis seeds must be conducted at temperatures from 25 to $30^{\circ} \mathrm{C}$.

2. The temperature of $20^{\circ} \mathrm{C}$ is the minimum for germination and those above $35^{\circ} \mathrm{C}$ are lethal to the seeds.

3. The substrate most favorable to the germination of $P$. volubilis seeds is micron or fine vermiculite.

\section{Literature Cited}

Alves, M. M.; Alves, E. U.; Araújo, L. R. de; Araújo, P. C.; Santos Neta, M. M. S. Crescimento inicial de plântulas de Adenanthera pavonina L. em função de diferentes substratos. Revista Ciência Agronômica, v.46, p.352-357, 2015.

Banzatto, D. A.; Kronka, S. N. Experimentação agrícola. 4.ed. Jaboticabal: FUNEP, 2006. 237p.

Bioplant - Produzindo qualidade. http://www.bioplant.com.br/. 21 Set. 2015.

Borges, E. E. de L.; Toorop, P. E. Fisiologia da germinação. In: Piña-Rodrigues, F. C. M.; Figliolia, M. B.; Silva, A. da. Sementes florestais tropicais: Da ecologia à produção. Brasília: ABRATES, 2015. p.244-258.

Brasil. Ministério da Agricultura, Pecuária e Abastecimento. Regras para análise de sementes. Brasília: MAPA/ACS, 2009. 399p.

Brasil. Ministério da Agricultura, Pecuária e Abastecimento. Instruções para análise de sementes de espécies florestais. Brasília: Secretaria Nacional de Defesa Agropecuária/MAPA/ACS, 2013. 98p.

Carvalho, N. M. de; Nakagawa, J. Sementes: Ciência, tecnologia e produção. 5.ed. Jaboticabal: FUNEP, 2012. 590p. 
Dutra, T. R.; Massad, M. D.; Sarmento, M. F. Q.; Oliveira, J. C. Emergência e crescimento inicial da canafístula em diferentes substratos e métodos de superação de dormência. Revista Caatinga, v.25, p.65-71, 2012.

Ferraz, I. D. K.; Albuquerque, M. C. F.; Calvi, G. P.; Farias, D. L. Critérios morfológicos e temperatura para avaliação da germinação das sementes de cupuaçu. Revista Brasileira de Fruticultura, v.34, p.905-914, 2012. http://dx.doi.org/10.1590/ S0100-29452012000300033

Follegatti-Romero, L. A.; Piantino, C. R.; Grimaldi, R.; Cabral, F. A. Supercritical $\mathrm{CO}^{2}$ extraction of omega-3 rich oil from sacha inchi (Plukenetia volubilis L.) seeds. The Journal of Supercritical Fluids, v.49, p.323-329, 2009. http://dx.doi.org/10.1016/j. supflu.2009.03.010

Gutiérrez, L. F.; Rosadab, L. M.; Jiménez, A. Chemical composition of sacha inchi (Plukenetia volubilis L.) seeds and characteristics of their lipid fraction. Grasas y Aceites, v.62, p.76-83, 2011. http:// dx.doi.org/10.3989/gya044510

Hamaker, B. R.; Valles, C.; Gilman, R.; Hardmeier, R. M.; Clark, D.; Garcia, H. H.; Gonzales, A. E.; Kohlstad, I.; Castro, M.; Valdivia, R.; Rodriguez, T.; Lescano, M. Amino acid and fatty acid profiles of the Inca Peanut (Plukenetia volubilis). Cereal Chemistry, v.69, p.461-463, 1992.

Kapoor, N.; Arya, A.; Siddiqui, M. A.; Kumar, H.; Amir, A. Physiological and biochemical changes during seed deterioration in aged seeds of rice (Oryza sativa L.). American Journal of Plant Physiology, v.6, p.28-35, 2011. http://dx.doi.org/10.3923/ ajpp.2011.28.35

Labouriau, L. G.; Valadares, M. E. B. On the germination of seeds Calotropis procera (Ait.) Ait.f. Anais da Academia Brasileira de Ciências, v.48, p.263-284, 1976.

Lima, J. F.; Silva, M. P. L.; Teles, S.; Silva, F.; Martins, G. N. Avaliação de diferentes substratos na qualidade fisiológica de sementes de melão de caroá [Sicana odorifera (Vell.) Naudim]. Revista Brasileira de Plantas Medicinais, v.12, p.163-167, 2010.

Lopes, H. dos S.; Castilho, R. M. M. de; Lopes, H. dos S. Germinação e crescimento inicial de plântulas de melancia em diferentes substratos comerciais. Tecnologia \& Ciência Agropecuária, v.7, p.25-29, 2013.

Lopes, J. C.; Pereira, M. D. Germinação de sementes de cubiu em diferentes substratos e temperaturas. Revista Brasileira de Sementes, v.27, p.146-150, 2005. http://dx.doi.org/10.1590/S010131222005000200021

Maguire, J. D. Speed of germination: Aid in selection and evaluation for seedling emergence and vigour. Crop Science, v.2, p.176-177, 1962. http://dx.doi.org/10.2135/cropsci1962.0011183X000200020033x
Martins, C. C.; Borges, A. da S.; Pereira, M. R. R.; Lopes, M. T. G. Posição da semente na semeadura e tipo de substrato sobre a emergência e crescimento de plântulas de Schizolobium parahyba (Vell.) S.F. Blake. Ciência Florestal, v.22, p.849-856, 2012. http:// dx.doi.org/10.5902/198050987565

Martins, C. C.; Caldas, I. G. R.; Machado, C. G.; Dourado, W. S. Tipos de substratos para germinação de sementes de palmeirareal-australiana (Archonto phoenix alexandrae H. Wendl. \& Drude). Revista Árvore, v.35, p.1189-1196, 2011. http://dx.doi. org/10.1590/S0100-67622011000700005

Nakagawa, J. Testes de vigor baseados no desempenho das plântulas. In: Krzyzanoski, F. C.; Vieira, R. D.; França Neto, J. B. (ed.). Vigor de sementes: Conceitos e testes. Londrina: ABRATES, 1999. p.2.1-2.24.

Pascuali, L. C.; Silva, F. S. da; Porto, A. G.; Silva Filho, A. da; Meneghello, G. E. Germinação de sementes de pinhão manso em diferentes temperaturas, luz e substratos. Semina: Ciências Agrárias, v.33, p. 1435-1440, 2012. http://dx.doi.org/10.5433/16790359.2012v33n4p1435

Ruiz, C.; Díaz, C.; Anaya, J.; Rojas, R. Análisis proximal, antinutrientes, perfil de ácidos grasos y de aminoácidos de semillas y tortas de 2 especies de sacha inchi (Plukenetia volubilis y Plukenetia huayllabambana). Revista de la Sociedad Química del Perú, v.79, p.29-36, 2013.

Sena, L. H. de M.; Matos, V. P.; Ferreira, E. G. B. de S.; Sales, A. G. de F. A.; Pacheco, M. V. Qualidade fisiológica de sementes de pitangueira submetidas a diferentes procedimentos de secagem e substratos - Parte 1. Revista Brasileira de Engenharia Agrícola e Ambiental, v.14, p.405-411, 2010. http://dx.doi.org/10.1590/ S1415-43662010000400009

Silva, R. B. G. da; Silva, M. R. da; Simões, D. Substrates and controlledrelease fertilizations on the quality of eucalyptus cuttings. Revista Brasileira de Engenharia Agrícola e Ambiental, v.18, p.11241129, 2014. http://dx.doi.org/10.1590/1807-1929/agriambi. v18n11p1124-1129

Ugarte, J. F. O.; Sampaio, J. A.; França, S. C. A. Vermiculita. In: Luz, A. B.; Lins, F. A. F. (org.). Rochas \& minerais industriais - Usos e especificações. Rio de Janeiro: CETEM/MCT, 2005. p.677-698.

Varela, V. P.; Costa, S. S.; Ramos, M. B. P. Influência da temperatura e do substrato na germinação de sementes de itaubarana (Acosmium nitens (Vog.) Yakovlev) - Leguminosae, Caesalpinoideae. Acta Amazônica, v.35, p.35-39, 2005. http://dx.doi.org/10.1590/S004459672005000100006

Weitbrecht, K.; Müller, K.; Leubner-Metzger, G. First off the mark: Early seed germination. Journal of Experimental Botany, v.62, p.3289-3309, 2011. http://dx.doi.org/10.1093/jxb/err030 